Article title: Student Support at Unisa: A Flowing-River Metaphor

Authors: Gladys Mokwena[1]

Affiliations: Department of Adult Education and Youth Development, University of South Africa[1]

Orcid ids: 0000-0002-8760-7563[1]

Contact e-mail: leanobontle19@gmail.com

License information: This work has been published open access under Creative Commons Attribution License $\mathrm{http}: / / c r e a t i v e c o m m o n s . o r g / l i c e n s e s / b y / 4.0 /$, which permits unrestricted use, distribution, and reproduction in any medium, provided the original work is properly cited. Conditions, terms of use and publishing policy can be found at https://www.scienceopen.com/.

Preprint statement: This article is a preprint and has not been peer-reviewed, under consideration and submitted to UnisaRxiv for open peer review.

Funder: College of Education, Unisa

DOI: 10.25159/UnisaRxiv/000022.v1

Preprint first posted online: 31 May 2021

Keywords: Connectivism, flowing-river metaphor, higher certificate programme, lecturer, student support, virtual 


\section{Student Support at Unisa: A Flowing-River Metaphor}

\section{Gladys Kedibone Mokwena}

https://orcid.org/0000-0002-8760-7563

Department of Adult Education and Youth Development, University of South Africa mokwegk@unisa.ac.za

leanobontle19@gmail.com

\section{Abstract}

The flowing-river metaphor is explored in this paper for the Unisa Department of Adult Education's higher certificate programme student support. It is a qualitative case study, grounded in Connectivism. It involves seven lecturers' reflections of using the elements of the flowing-river metaphor on the way in which technology has reorganised lecturers' interactions when providing support to students in teaching and learning. Virtual talking circles on the Microsoft Teams forum, a review of departmental reports on student support, and my reflection on the experiences of higher certificate lecturers when providing student support in teaching the module material are the main data gathering tools. The flowing-river metaphor, on the other hand, uses the contrast between vehicle and target to help higher certificate students to develop their teaching and learning. In this case, the complexity of using available resources varies from lecturer to lecturer. The paper encourages other higher education lecturers to think more carefully about the flowing-river metaphor's potential as a pedagogical guide for student support.

Keywords: Connectivism, flowing-river metaphor, higher certificate programme, lecturer, student support, virtual

\section{Introduction}

Student support is at the centre of teaching and learning, and is a striking feature of validating diverse human capabilities at institutions of higher learning, even more so, at open distance learning (ODL) institutions. Using the flowing-river metaphor I reflect on student support provided to the typical students who enrol for the higher certificate programme. Some of the students have just graduated from high school, others are new in the ODL environment and are not working, or they are working adults without bachelors' degrees and use the higher certificate programme as a bridging course.

Arguably, as a former distance learner and now a lecturer in an ODL institution, the most important thing for any student at an ODL institution is the feeling of support. The University of South Africa (Unisa), like its counterparts, has become a vehicle for bringing lifelong education to diverse students in ODL environments (Pittman as quoted in Moore and Anderson 2003; Simpson 2006). In the last decade, the higher education 
environment in Africa and around the world has drastically changed. There were many changes that could not be ignored as the dawn of a new era began; these include the transforming and rebuilding of the major social institutions to redress the vast challenges of inequality, poverty and the need for economic growth. In addition, decolonisation in institutions of higher learning also calls for access to student support and learning opportunities in the context of the student's language and cultural backgrounds (Heleta 2016). This means, that to embrace student diversity in institutions of higher learning, the representation of different cultures, more so in South Africa, where 11 official languages are spoken, should be considered.

My use of the flowing-river metaphor has the potential to fulfil this mandate as Botha (2009) argues that metaphors play an important aesthetic, ornamental, and pedagogical role in both literature and education. In a similar manner, Mokwena (2020) asserts that using the metaphor of a flowing river would help teachers to be more creative. As a result, this paper will discuss the lecturers' role in promoting student support using the metaphor of a flowing river. Although this paper does not claim to present an exhaustive account of the flowing-river metaphor in explaining the processes of student support in teaching and learning, the examples in Table 1 provide some indication of the different elements in the flowing-river metaphor, a strategy I have adopted as a teacher to interact with students in diverse contexts (Mokwena 2020).

Table 1: The flowing-river metaphor

\begin{tabular}{|l|l|}
\hline Elements of the flowing river & Guiding questions \\
\hline Every river has a beginning. & $\begin{array}{l}\text { What is the source of providing student } \\
\text { support? }\end{array}$ \\
\hline $\begin{array}{l}\text { The river flows and gives birth to } \\
\text { tributaries. }\end{array}$ & $\begin{array}{l}\text { What tools help you to provide student } \\
\text { support? }\end{array}$ \\
\hline $\begin{array}{l}\text { The river attracts various forms of } \\
\text { fauna and flora. }\end{array}$ & $\begin{array}{l}\text { How has student support developed in the } \\
\text { higher certificate programme modules? }\end{array}$ \\
\hline $\begin{array}{l}\text { The river goes through some uneven } \\
\text { surfaces and rocks. }\end{array}$ & $\begin{array}{l}\text { What are the obstacles and challenges } \\
\text { experienced in student support practices? }\end{array}$ \\
\hline $\begin{array}{l}\text { The river dries out at some point but } \\
\text { other tributaries still find their way } \\
\text { through and meet again. }\end{array}$ & $\begin{array}{l}\text { How do you overcome challenges to } \\
\text { enhance student support? }\end{array}$ \\
\hline The river widens and runs gently. & $\begin{array}{l}\text { How do you maintain support for diverse } \\
\text { students registered for your module? }\end{array}$ \\
\hline Every river has a destination. & $\begin{array}{l}\text { What is your deepest desire for providing } \\
\text { student support? }\end{array}$ \\
\hline
\end{tabular}

https://blog.iese.edu/rosenberg/2012/01/17/career-management-1-what-to-do-and-themetaphor-of-the-river/ 


\section{Development of Student Support}

In this paper, the concept of student support is used interchangeably with learner support. Tait (2000) defines the term student support as the range of services both for individuals and for students in groups which complement the course material or learning resources that are uniform for all learners. Tait (2003) averred that student support recognises the distance between teaching and learning in ODL. Later, Tait (2014) sought to put perspective on the ways in which support to students should be reconceived in the digital age for distance and e-learning. Tait's diverse definition of student support relates to the element of the flowing-river metaphor as the river flows, gives birth to tributaries and attracts various forms of fauna and flora. Similarly to Tait $(2003,2015)$, the author highlights the importance of openness in ODL for student support. In the same study, Tait (2015) points out that social status and gender are eroding as barriers to student support in higher education institutions.

In contrast, Simpson (2006) views student support as all activities beyond the production and delivery of course materials that assist in the progress of students in their studies. In another study, Simpson (2006) refers to student support as the provision of other forms or backup apart from the text. Student support is, therefore, an inevitable means to provide as backup support for their teaching and learning endeavours. It is in this regard that Unisa introduced the online learning management system (LMS) to help academics and support staff to use the various platforms and to enhance student support practices online. For higher certificate students who just graduated from high school, the ODL environment seem to be like the river drying out as the students find themselves isolated from the institution, their teachers and peers because of the new environment. Following that, Tait's $(2014,5)$ statement that "service to students should be reconceived in the digital era for distance and e-learning" is ideal for familiarising students and improving student support.

Unisa, as an institution of higher learning, is the oldest and biggest ODL institution in Africa (Isabirye and Makoe 2018; Pityana 2008; Prinsloo and Coetzee 2013). The institution provides various learner support systems which include e-tutoring, online discussion forums as well as community learning centres providing tutorial support, counselling services and peer-group support. These centres provide a place where students can meet, attend classes and discussion groups, study, and collect books and other materials for learning. Where it is not possible to offer face-to-face tutoring, teletutoring (telephone, video, and computer-conferencing) with lecturers is also used to support communication between the teacher and the learner.

With the radical intrusion of a range of technologies, principally those grouped around ODL environments, more than 20000 students registered for the higher certificate modules, and it is envisaged that they may complete them in two semesters. The modules' course names and codes are listed as follows: 
- Contextual Studies (ABT1512)

- Exploring Adult Learning (ABT1513)

- Planning and Administering ABET Classes and Projects (ABT1515)

- Introduction to Assessment in ABET (ABT1516)

- Teaching Literacy to Adults (ABT1517)

- Teaching Numeracy to Adults (ABT1518)

- Teaching Adult Basic Education (ABT1519)

- Building a Portfolio of ABET Practice (ABT1520)

\section{Challenges Faced in Student Support}

Despite the well-meant intent of placing student support at the centre of teaching and learning in ODL, students, especially those from disadvantaged environments, still find it extremely difficult to adjust to and succeed in ODL (Prinsloo and Coetzee 2013). As a result, the present landscape of education in South Africa could not escape the prevailing political, economic and social factors of its creation. There are distinctive social conditions that precede and accompany the students as they enter institutions of higher learning.

Students' success is accompanied by difficulties in their adaptation to the new learning environment and even more so for the current students who are much younger and inexperienced in the dynamics of institutions of higher learning. Unisa's attempt to deal with the call for providing accessible and affordable learning opportunities to all students regardless of their background, seems impossible (Prinsloo and Coetzee 2013). A reflection on the provision of student support in the higher certificate course seems challenging since the level of support varies from one lecturer to another. Students, on the other hand, may still be acclimatising to this environment and some have never used a computer throughout their basic education. Others might be unable to participate in available student support platforms because of limited access to online tools, owing to a lack of internet resources.

Students might also have insufficient financial resources to travel to regional centres to access computers. Furthermore, not all students take part in the platforms that include discussion postings and announcements from lecturers or e-tutors.

The critical problems that institutions of higher learning are faced with are student retention, a high dropout rate, and a low throughput rate (Directorate of Information and Analysis https://www.unisa.ac.za). This is confirmed by the Report of the Council of Higher Education on a proposal for undergraduate curriculum reform in South Africa: The case for a flexible curriculum structure revealed that 50 per cent to 60 per cent of students drop out of tertiary institutions (https://www.che.ac.za). Unlike other 
institutions of higher learning, which provide face-to-face student support, a problem peculiar to Unisa relates to higher certificate students' low use of online support as a result of various challenges (Joubert and Snyman 2018). These include challenges experienced by e-tutors in providing support to students who prefer direct interaction with their lecturers.

According to Jakovljevic, Buckley and Bushney (2014), it is assumed that ill-prepared students are entering the ODL spaces and are performing their study tasks in isolated environments. I acknowledge, as one of the primary lecturers in the higher certificate, that all learners are different and learn differently. It is in this regard that lecturers in the Department of Adult Education use various online platforms to provide varied student support. A study by Qakisa-Makoe (2005) identifies the main purpose of student support as providing an environment that improves students' commitment and motivation to learn. Considering the large number of students in the higher certificate course, which often ranges from 2000 and 20000 per module per semester, one asks oneself how efficiently one can create an efficient environment for diverse students per semester. McEwan (2007) explores the underlying assumptions of metaphors; of relevance to this paper is the role of the teacher (lecturer) as coach.

Arguably, student support is one of the hallmarks of quality teaching and learning and is essential for providing opportunities for enhancing student motivation and success. Yet, despite the availability of a variety of student support practices, extensive literature reviews conducted on student support reveal that there are discrepancies among academics of different institutions in the use of tools available for providing environments in ODL that are conducive to student support (Isabirye and Makoe 2018; Prinsloo and Coetzee 2013).

The aforementioned discrepancy can be attributed to the context in which each institution of higher learning is operating. Some institutions provide student support to a manageable number of learners on a face-to-face basis (Simpson 2006), while Unisa's higher certificates programme of the College of Education (CEDU) must provide student support to thousands of diverse students in the ODL context. This situation made the lecturers in the Department of Adult Education, offering first-year modules, to reflect on the way in which support practices can be enhanced for diverse students within an ODeL environment. To overcome the myriad of factors that surround student support, this paper aims to identify lecturers' student support practices in the higher certificate programme. These practices can be used and shared across Unisa's lecturer community, to support students in the teaching and learning of module content. Furthermore, the practices can be shared in the college's teaching and learning platforms which include seminars, conferences and training workshops. The next section discusses theoretical frameworks in relation to student support practices. 


\section{Theoretical Framework}

Connectivism was used in the paper to focus on the way in which the theoretical underpinnings speak to the way in which technology has reorganised how we work, interact, and learn (Siemens 2005).

The theory seems appropriate to explore students' learning needs to describe learning processes essential for their support.

\section{Connectivist Student Support}

Connectivism has a variety of definitions. In this paper, I use the definition as first suggested by Siemens and Downes (2015) and Siemens (2005) who saw Connectivism as a learning theory that explains the way in which internet technologies have created new opportunities for people to learn and share information across the World Wide Web and among themselves.

According to Siemens (2005), this theory is fast becoming the key trend in enhancing interaction with others in ODL. Important to the theory is the community that is created through the networks used. The theory of Connectivism seems relevant for this paper, primarily because it affords the distance learner the right to be reckoned with and to feel in charge. In addition, Connectivism enables lecturers to engage, share and receive feedback from diverse students simultaneously through internet technologies. In Freire's (2007) banking concept, student support was seen as a one-way street driven by the teacher. Connectivism would also support Freire's idea of providing education for the masses; releasing them from oppression through the community of networks. However, through Connectivism, student support is viewed as a learner-centred teaching perspective in which active involvement for both the teacher and student is promoted. Applying the theory of Connectivism, the lecturer may suggest an online support system and afford the students the opportunity to make a choice about the platforms that are meaningful for them. Through online group discussions, students support one another in a collaborative manner.

Brindley and Paul (2004) explain that student support services should be student-centred for ODL to be successful. They point out:

An effective student support service in distance education is characterised by responsiveness to students' needs, that is, it personalises the learning process; it encourages and facilitates interaction between students and stakeholders; it facilitates learning within courses. (Brindley and Paul 2004, 45)

Considering the diverse students' backgrounds, incorporating Connectivism into student support somehow poses a threat to students who lack resources such as internet resources or finances to travel to the nearest regional centres, more so in crisis times such as the Covid-19 pandemic. In this regard, the digital divide separates those with 
technology from those without technology. The theory might have created new opportunities for people to learn and share but it might not be accessible to all.

\section{Research Method}

An interpretive paradigm informed the design of this research. In the interpretive paradigm, taking people's experiences as the essence of what is real for them is crucial (Creswell 2014). A case study was selected in this paper as the author used it as both a research design and a teaching method. As a research design, case studies are used in a variety of contexts such as in communities and organisations, individuals, and social and political phenomena which provide an understanding of the experiences of the concerned lecturers about student support. Data collection was done after ethical approval was obtained from the College of Education at Unisa. The author's main data gathering instruments involved (virtual) talking circles, which viewed, as an example, a focus group method derived from postcolonial indigenous worldviews and use of the departmental reports on student support, and the author's reflections.

\section{Data Analysis}

The aim of this research was to explore a flowing-river metaphor for student support in an ODL environment. The analysis of data was guided by Miles and Huberman's (1994) three main stages of data analysis which enable the author to infuse the guiding questions in Table 1, as co-researcher with other higher certificate lecturers to explore student support. As a result, the following themes were identified:

- lecturers' facilitation of student support using diverse online tools;

- lecturers and student interaction towards familiarisation of module content; and

- student support for examination preparation.

\section{Findings and Discussions}

The first virtual discussion occurred on the Microsoft Teams platform, which is a collaboration app of Microsoft 365 (https://www.microsoft.com/en-za/microsoftteams) that helps teams to stay organised and have conversations. Through this platform there is integration among people, content and tools for teams in the workplace or any other setting. A common practice is lecturers' use of tutorial letters 101, 102, and 201s as a way of communicating with students about teaching and learning the module content.

\section{Theme1: Lecturers' Facilitation of Student Support Using Diverse Online Tools}

The observation was confirmed in the first virtual discussion by Lecturer 7 who explained: 
As soon as registration closes, my first interaction with students in my module is to welcome them on myUnisa platform as their primary lecturer.

Raising their hand virtually, Lecturer 4 added:

Considering the +20000 students I handle per semester, I utilise myUnisa to reach out to a large number of students across the country posting announcements as need arise. Those that participate actively in the discussion postings appreciate my support and communicate on an on-going basis.

In terms of communicating with the students, the source of the river flowing brought several tributaries through the institution's LMS. Subsequently, students can continue with teaching and learning regardless of the location they are placed.

In the second session, Lecturer 5 shared their long experience of teaching higher certificate programme and added:

Most students who enrol in ABT Certificate are not familiar with the ODL environment. I utilise the telephone or email to respond to student's queries. I keep a record of the intervention I have provided; I also have interactive meetings with students online using myUnisa.

The lecturers' practice contributes to the enhancement of student support in the new ODL environment. The lecturers' responses corroborate with Brindley and Paul's (2004) findings, which point out the important role of practitioners in ODL in helping students become more independent, collaborative and effective learners. Using the flowing-river metaphor, it can be said, instead of lecturers meandering like a river, they play a facilitative role to assist students with the online tools at their disposal.

\section{Theme 2: Lecturers and Student Interaction towards Familiarisation of Module Content}

A week later, the second virtual discussion was held on Microsoft Teams with lecturers raising several issues about student support towards familiarisation of module content. Again, Lecturer 5 said that at the time of joining the department, her previous work experience was on the traditional face-to-face teaching. Her concern was that she did not have a clue about the ODL environment.

A key theme that emerged from the discussion was the use of digital technology to enhance student support practices. Lecturer 5 posted on the chat box and pointed out that:

I have learnt to use video communication to encourage students in my module to create knowledge through dialogue and the sharing of different perspectives. Through video conference, I not only create space for new communication between myself and students, but also encourage critical dialogue that support thinking and reflection. 
The lecturer's words resonate with the flowing-river metaphor that they too, including students, like the river sometimes go through uneven surfaces and rocks of life. The challenges experienced may be attributed to the lack of technology or difficulty in using the available technology. Instead of getting stuck on the obstacle, lecturers find their way through by familiarising themselves with available online tools such as video conferencing and Tippy Tube for the sole purpose of being physically present in alignment with the institutions ODL policy.

In broadening the familiarisation of the module content, another higher certificate lecturer, Lecturer 2 explained:

I encourage students to link the module content with the Sustainable Development Goals and other national policies. This helps them to link theory learnt in the module with practical realities.

The response of Lecturer 2 indicates that just as the river widens and deepens, she plays a mediator role to help students integrate the learning programmes with contemporary issues. Students are members of the community; their qualification must be relevant to the needs of their communities. By so doing, the lecturer helps the students to deepen their knowledge to current issues in the community. The author draws from her colleagues that relevance can help students realise how useful knowledge can be and is an essential element of student support.

\section{Theme 3: Student Support for Examination Preparation}

In the third and final virtual circle, the higher certificate programme lecturers shared their experiences of student support for examination preparation. Lecturer 1 highlighted her experience of supporting students for examination preparation as follows:

Just before students write their semester examination, I have video conferencing. I can communicate with students from different regions simultaneously, interacting with students on various aspects of the module.

The lecturer's role as a coach is defined by their understanding of the way in which to provide knowledge and understanding support to their students. In this way, the lecturer serves as the tributary providing support to students. Conversely, Lecturer 6's view of student support for examination preparation was focused on her interaction with external markers. She said:

I encourage external markers to give detailed comments when marking students' assignments. With constructive feedback, students are given the support that will help them in preparing for the examination.

The lecturers' responses reveal that ongoing support is essential to help students to prepare effectively to avoid common mistakes and handle stress. 


\section{Conclusion}

It can be concluded that as the river widens and deepens owing to circumstances beyond our control, lecturers can develop innovative and inclusive ways of student support. The flowing-river metaphor can be a useful strategy to be used for enhancement of student support in institutions of higher learning, more so in the ODeL context. In this regard, when students are confronted with a myriad of challenges, using metaphors can be a useful tool to help students identify alternative ways of thinking about these matters and above all critical alternative ways of thinking.

\section{Recommendations}

Enhancing student support is not a path that academics can walk alone. As the river widens and deepens, owing to external factors such as the Covid-19 pandemic, it is important to note that student support is a non-negotiable backup aspect for students' teaching and learning. The author's recommendation is therefore to present the concept of metaphors as teaching strategy to co-lecturers and programme managers with the intention to pursue student support virtually in the second phase of the Scholarship of Teaching and Learning Writing project. Furthermore, provision of an inclusive support which strategically embraces students irrespective of their background is recommended. The author would then pursue pioneering virtual talking circles for student-centred support in the higher certificate programme. To succeed in this venture, the author will need to adopt a team approach in which higher certificate lecturers, the programme manager, e-tutors, external markers, and administrators are involved.

\section{References}

Botha, E. 2009. "Why Metaphor Matters in Education.” South African Journal of Education. 29: 431-44. https://doi.org/10.15700/saje.v29n4a287.

Brindley, J. E., and R. Paul. 2004. "The Role of Learner Support in Institutional Transformation - A Case Study in the Making." In Learner Support in Open, Distance and Online Learning Environments, edited by J. E. Brindley, C. Walti and O. Zawacki-Richter, 39-50. Oldenburg: Bibliotheks - und Informations system der Universität Oldenburg.

Creswell, J. W. 2014. Research Design: Qualitative, Quantitative and Mixed Methods Approaches. 4th ed. Thousand Oaks: Sage.

Freire, P. 2007. Pedagogy of the Oppressed. New York: Continuum.

Heleta, S. 2016. "Decolonisation of Higher Education: Dismantling Epistemic Violence and Eurocentrism in South Africa." Transformation in Higher Education 1 (1): 1-8. https://doi.org/10.4102/the.v1i1.9. 
Isabirye, A., M. Makoe. 2018. "Phenomenological Analysis of the Lived Experiences of Academics who Participated in the Professional Development Programme at an Open Distance Learning University in South Africa." Indo-Pacific Journal of Phenomenology 18 (1): 1-11. https://doi.org/10.1080/20797222.2018.1450764.

Jakovljevic, M., S. Buckley, and M. Bushney. 2014. "Well-Designed Communities of Practice in the ODeL Environment: Students' Perspectives." Independent Journal of Teaching and Learning 9: 44-61.

Joubert, Y. T., and A. M. Snyman. 2018. "Challenges Experienced with Online Tutoring in an ODL Institution.” Progressio: South African Journal for Open and Distance Learning Practice 39 (1): 126-45. https://doi.org/10.25159/0256-8853/2139.

McEwan, A. E. 2007. "Do Metaphors Matter in Higher Education?” Journal of College and Character VIII (2). https://doi.org/10.2202/1940-1639.1166.

Miles, M. B., and A. Huberman. 1994. Qualitative Data Analysis: An Expanded Sourcebook. Thousand Oaks: Sage.

Mokwena, G. K. 2020. "The Metaphor of the Flowing River for Teaching Adult Literacy in a Correctional School." In The Pedagogy Employed for Correctional Education: An Ubuntu and Wellness Perspective and the Pedagogy of Intervening using Inclusivity in a Special School for Leaners with Intellectual Disabilities: A Wellness Perspective from Theory to Practice in Embracing African Values of Botho/Ubuntu, edited by M. D. Magano and L. Dreyer. Reach.

Moore, M. G., and W. A. Anderson. 2003. Handbook of Distance Education. London: Lawrence Erlbaum.

Pityana, B. 2008. "A Decade of Development and Education in Africa: The Promise of Open Distance Learning.” Keynote address at UNESCO, London, 14-16 July 2008.

Prinsloo, P., and M. Coetzee. 2013. "Initiating the Debate: Perspectives on Teaching, Learning and Assessment in ODL Contexts." South African Journal of Higher Education 27 (6): 1355-65.

Qakisa-Makoe, M. 2005. "Reaching Out: Support Black : Learners in Distance Education." Progressio 27 (1-2): 44-61.

Siemens, G. 2005. "Connectivism: A Learning Theory for the Digital Age.” International Journal of Instructional Technology and Distance Learning 2 (1). http://www.itdl.org/.

Siemens and Downes. 2015. “Connectivism.” Accessed 3 July 2018. https://www.learningtheories.com/connectivism siemens-downes.html.

Simpson, O. 2006. "Predicting Student Success in Open and Distance Learning." Journal of Open, Distance and e-Learning 21 (2): 125-38.

https://doi.org/10.1080/02680510600713110. 
Tait, A. 2000. "Planning Student Support for Open and Distance Learning." Open Learning: The Journal of Open, Distance and E-Learning 15 (3): 287-99. http://doi.org/10.1080/713688410.

Tait, A. 2003. "Reflections on Student Support in Open and Distance Learning." International Review of Research in Open and Distance Learning. https://doi.org/10.19173/irrodl.v4i1.134.

Tait, A. 2014. "From Place to Virtual Space: Reconfiguring Student Support for Distance and E-Learning in the Digital Age.” Accessed 22 August 2019. https://doi.org/10.5944/openpraxis.6.1.102.

Tait, A. 2015. "Student Success in Open, Distance and E-Learning." Oslo: International Council for Open and Distance Learning. https://www.icde.org/assets/WHAT_WE_DO/studentsuccess.pdf. 